\title{
Sosyal Kırılganlık İndeksinin CBS ile Haritalanması: İzmir İli Örneklemi
}

\author{
Zeynep ORTAKAVAK ${ }^{1}$, Ahmet USLU ${ }^{2}$, Engin KORKMAZ ${ }^{3}$
}

Öz

Günümüzde, doğal afetler veya beşerî etkilerle üretilmiş mekânsal riskler, hızla artan dünya nüfusunu daha da fazla tehdit eder olmuştur. Çarpık kentleşme, plansız yapılaşma ve insanlığın, yeryüzünü bilinçsizce kullanımı, afet durumlarındaki kayıpların artmasına yol açmaktadır. Bu durum, risk öncesi ve sonrası planlama ve yönetim aşamalarında, daha etkili kararlar alınması gerekliliğini ortaya çıkarmıştır. Afet yönetiminde, yalnızca fiziki etkenler değil, toplumun sosyoekonomik ve demografik yapısı da göz önünde bulundurulmalıdır. Bu bağlamda, "sosyal kırılganlık" kavramı öne çıkmaktadır. Aynı kategori içerisindeki, diğer insanlara karşı dezavantaja sahip grup olarak tanımlanabilen kırılgan grupların tespiti, risk anı, öncesi ve sonrası açısından büyük önem arz etmektedir. Tehlikelerden korunma ve yeniden yapılanma aşamalarında, risklere karşı toplumdaki birey ve grupların savunmasızlığını ölçen kırılganlık kavramı, mekânsal verilerle entegre edildiğinde daha başarılı sonuçlar elde edilebilmektedir. Zira, toplumu mekân ve sosyo-politik değişkenlerden ayrı değerlendirmek eksik bir yaklaşım olacaktır. Bu noktada, mekânsal problemlere karşı güçlü karar destek sistemlerine sahip olan Coğrafi Bilgi Sistemleri (CBS), kırılganlık analizlerinde aranılan araçlardan olmuştur. Sosyal kırılganlık değerlerinin spesifik bir alanda incelendiği bu çalışmada, İzmir iline ait sosyal kırılganlık indeksi (SoVI) hesaplanıp, CBS yöntemleriyle haritalandırılmıştır. Böylelikle, risk durumlarında öncelikli bölgelerin tespiti ve bu bölgelerdeki sosyal grupların niteliksel intiyaçlarına yönelik değerlendirme yapılması mümkün hale getirilmiştir.

Anahtar Kelimeler: afet yönetimi, cbs, sosyal kırılganlık indeksi

\section{The Mapping of Social Vulnerability Index by GIS: A Case Study of İzmir}

\begin{abstract}
For In recent time, spatial risks produced by natural disasters or human impacts have been threatening the rapidly growing world population. Distorted urbanization, unplanned construction and the unconscious use of human resources lead to an increase in losses in disastrous situations. This situation revealed the need to make more effective decisions in the planning and management stages before and after the risk. In disaster management, not only physical factors but also socioeconomic and demographic structure of society should be taken into consideration. In this context, the concept of "social vulnerability" stands out. Detection of vulnerable groups whom are disadvantageous groups of people, has great importance for dealing with risks before and after they occur. In the protection and recover stages, when the concept of vulnerability is integrated with spatial data, better results could be obtained. It is not appropriate evaluate the society apart from the spatial and socio-political variables. At this point, Geographical Information

\footnotetext{
${ }^{1}$ Uzaktan Algılama ve Coğrafi Bilgi Sistemleri Ana Bilim Dalı, Lisansüstü Eğitim Enstitüsü, Eskişehir Teknik Üniversitesi, Eskişehir, Türkiye

2 Mimarlık ve Şehir Planlama Bölümü, Dumlupınar Üniversitesi, Tavşanlı Meslek Yüksek Okulu, Kütahya, Türkiye

${ }^{3}$ Uzaktan Algılama ve Coğrafi Bilgi Sistemleri Ana Bilim Dalı, Lisansüstü Eğitim Enstitüsü, Eskişehir Teknik Üniversitesi, Eskişehir, Türkiye

*ilgili yazar / Corresponding author: zeyneportakavak@gmail.com
}

Gönderim Tarihi: 02.04.2019
\end{abstract}

Kabul Tarihi: 29.06.2019

Bu makaleye atıf yapmak için- To cite this article Ortakavak, Z., Uslu, A., \& Korkmaz, E. (2019). Sosyal Kırılganlık İndeksinin CBS ile Haritalanması: İzmir İli Örneklemi. Resilience, 3(1), 37-53. 
Systems (GIS), which have strong decision support systems against spatial problems, have been one of the tools required in the analysis of vulnerability. In this study, social vulnerability index (SoVI) of Izmir province was calculated and mapped with GIS methods. Thus, it was made possible to identify priority regions in risky situations and to evaluate the qualitative needs of social groups in these regions.

Keywords: disaster management, gis, social vulnerability index

\section{GíRiş}

Günümüzde, modern toplumun risklere karşı tutumunu etkileyen en önemli parametrelerden biri İngilizce'de "vulnerability" olarak kullanılan kavramdır. Türkçe'de ise bu kavram yapıların hasargörebilirliği, ekonomik zarargörebilirlik ve sosyal zarargörebilirlik veya sadece kırılganlık (hassasiyet, zayıflık, incinebilirlik ve savunmasızlık gibi) ile ifade edilebilmektedir. Tüm bu kavramların ortak noktası ise, bir risk unsurunun olması durumudur. Bir toplumsal gruba kırılgan grup diyebilmek için en önemli unsurun bir risk unsurunu taşıyor olması durumu olduğunu belirtmek gerekmektedir (Kuzucuoğlu, 2013).

Risk formüle edilirse, tehlikelerin gerçekleşme intimalinin, zarar/hasar görebilirlik ile çarpımıdır. Bir olgunun hasar görebilirliği ne kadar fazla ise tehlikenin gerçekleşmesi durumunda, o olgu üzerindeki hasar ve etkilenme de o ölçüde artmaktadır. Bu olgu; kent, toplum, kişiler veya maddeler olabilmektedir. Buradaki risk durumundan dolayı oluşan etkenler neticesinde ise kırılganlık hali vuku bulmakta, bu da temel fonksiyonların yerine getirilebilmesi için bir yardıma intiyaç duyulması hali, yani bir nevi bağımlılık, başkalarıyla iletişime geçmeyi engelleyen bir durumun bulunması ve saldırılardan, kötü davranışlardan, kötüye kullanımlardan korunamama durumu olarak tanımlanmaktadır.

$\mathrm{Bu}$ durum, toplum içindeki bazı gruplara uyarlanır ise; toplumun kırılgan kesimini oluşturan çocuklar, yaşılar, kadınlar, mülteciler ve özel gereksinimli bireyler gibi gruplar, olası bir tehlike durumunda başkalarının yardımına intiyaç duymaktadırlar. Kırılganlık kavramı belli başlıklar altında toplanacak olursa coğrafi, demografik, cinsiyet, yerleşim, sağlık, sosyal güvenlik, toplumsal çatışmalar, istihdam vb. başlıklar altında sıralanabilecek nedenlerden meydana gelmektedir (Tablo 1). Özellikle gelişmekte olan ülkeler açısından daha özel bir değerlendirme gerektiren bu durum, İnsani Gelişme Raporu'nda (2014) yer alan, aşağıdaki şekilde aktarıldığı gibi (Tablo 1) özellikle kadınlar, engelliler, göçmenler, azınlıklar, çocuklar, yaşlılar ve gençler gibi kırılgan gruplar doğal afetlere, iklim değişikliğine ve endüstri kazalarına karşı daha hassas ve daha kırılgan olmaktadır. Toplumların coğrafi konumlarından, sürdürülebilir kalkınma ve gelişmedeki yetersizlikleri ve sosyal kırılganlıkları afetlere dirençlilik kapasitesini azaltmaktadır. 
Tablo 1. Kırılganlık süreçleri

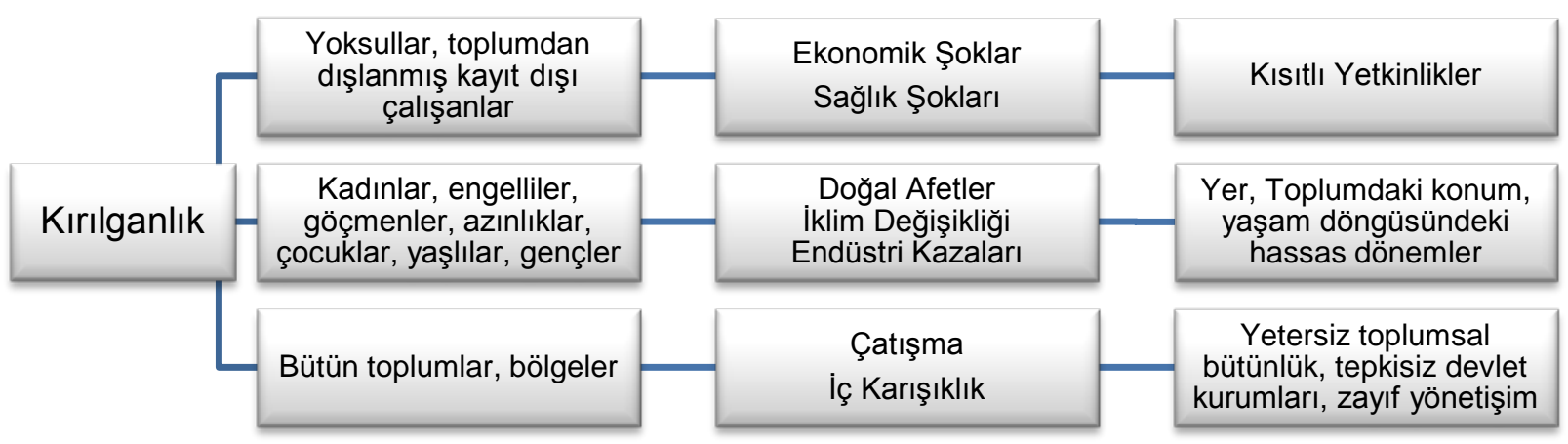

Kırılganlık değerlendirmesi anlaşılması güç süreçler gerektirmektedir. Zira, toplumlar arasındaki sosyal olgular değişkenlik gösterebildiği gibi, aynı toplumun kendi içerisinde de bir bütün halinde farklılık göstermekte, toplum içerisindeki bireylerin ve grupların sosyo-ekonomik göstergelerinin devamlı bir değişiklik gösterme eğiliminde bulunmaktadır. Bu da kırılganlık değerlendirme süreçlerini daha da karmaşık hale getirmektedir (Fuchs, 2012). Bu sürekli değişim, risklere maruz kalma ve kırılganlık arasında dinamik bir etki oluşturmaktadır. Hasar/Zarar görebilirliği ve sosyal kırılganlığı, sadece yapısal olarak değerlendirmek, bireysel ve bölgesel değişimlerin idaresi için yeterli değildir. Bu noktada, sosyal zarar görebilirlik anlamına gelen kırılganlık ile farklı pek çok kavramın ilişkisi devreye girmektedir. Kırılganlığın dinamik yapısı, süreklilik halinde, risklere karşı toplumsal savunmasızlık durumunu inceleyen yaklaşımlara intiyaç duymaktadır. Bu açıdan kırılganlık değerlendirmelerinin en azından ulusal bazda ve hatta daha spesifik alanlarda gerçekleştirilmesi, analizlerin daha sağlıklı yapılabilmesine neden olmaktadır.

Kırılganlık indeksinin (göstergeleri) mekânsal değerlendirmesi, toplumların afetlere karşı göstereceği tepkiyi yerel düzeyde değerlendirme imkânı sağlayarak, karar vericilere, risklere hazırlık ve risk azaltma planlarında yararlı bilgiler sağlamaktadır (Düzgün ve diğ. 2011; İBB, 2014; Menteşe ve diğ. 2015). Günümüzde, devletlerin, doğal ve beşerî etkilerle oluşturulmuş risklere karşı daha etkili politikalar yürütme gerekliliği fikrine, giderek artan bir ilgi gösterdiği ve risk değerlendirme, plan ve yönetim aşamalarında sosyal kırılganlık verilerini olmazsa olmaz unsurlardan saydığı gözlemlenmektedir.

Kırılganlık değerlendirmesinin bölgesel bazda incelendiği bu çalışmada, sosyal kırılganlık parametrelerini göstermek için alan bazlı yaklaşımlar kullanılmıştır. İzmir ili, ilçe ölçeğinde bağlamsal ve mekâna özgü verilerle oluşturan göstergeler belli metodolojik işlemlerden geçirilmiştir. Kırılganlık Göstergeleri Değerlendirmesi oluşturmak için, Temel Bileşenler Analizi (PCA) teknikleriyle kırılganlığa katkı sağlayan değişkenler analiz edilmiş, ArcGIS 10.4.1. coğrafi bilgi sistemleri araçlarıyla bölgesel ölçekte bazda haritalanmıştır. 


\section{2. ÇALIŞMA ALANI}

Bu çalışmada, çalışma alanı olarak İzmir ili seçilmiştir (Şekil 1.). İzmir, Türkiye'nin üçüncü büyük kentidir. 2017 nüfus sayımına göre İzmir'in nüfusu: 4.279.677'dir. Bu nüfus, 2.133.548 erkek ve 2.146.129 kadından oluşmaktadır. Yüzde olarak ise: \%49,85 erkek, \%50,15 kadındır. İzmir ilinin nüfus yoğunluğu ise, 347.67 (kişi/ $\left.\mathrm{km}^{2}\right)^{\prime}$ dir. Bu değer, Türkiye ortalamasının üzerindedir. Yüzölçümü ise $11891 \mathrm{~km}^{2}$,dir.

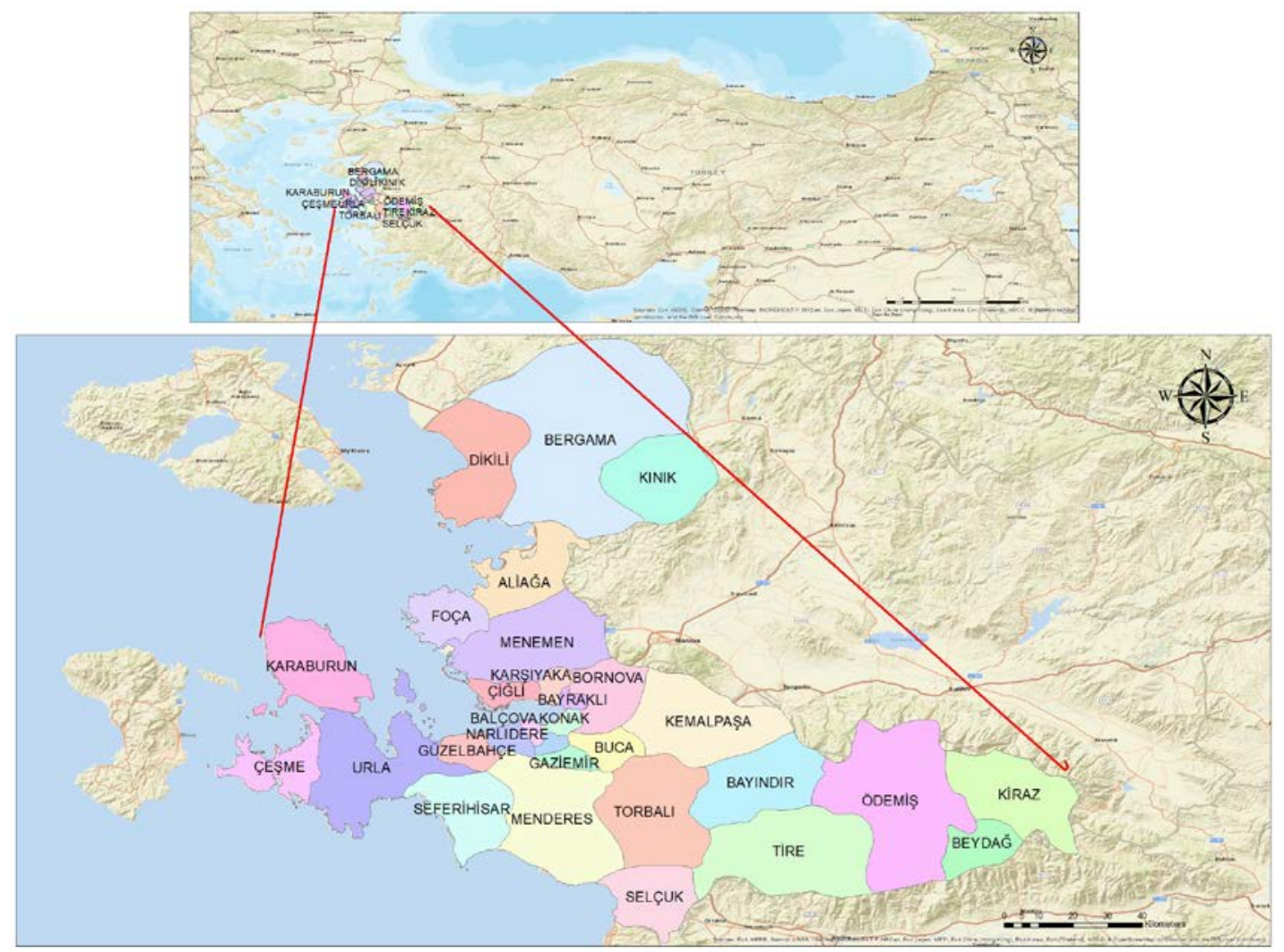

Şekil 1. İzmir ilinin coğrafi konumu

İzmir'in otuz adet ilçesi bulunmaktadır bunlar: Aliağa, Balçova, Bayındır, Bayraklı, Bergama, Beydağ, Bornova, Buca, Çeşme, Çiğli, Dikili, Foça, Gaziemir, Güzelbahçe, Karabağlar, Karaburun, Karşıyaka, Kemalpaşa, Kınık, Kiraz, Konak, Menderes, Menemen, Narlıdere, Ödemiş, Seferihisar, Selçuk, Tire, Torbalı, Urla'dır. Bunların yüzölçümü olarak en büyüğü;

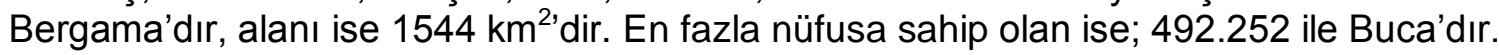

Coğrafi olarak ise kuzeyde, Madra Dağları, güneyde Kuşadası Körfezi, batıda Çeşme Yarımadası'nın Tekne Burnu, doğuda ise Aydın, Manisa il sınırları ile çevrilmiş İzmir ili, batıda kendi adıyla anılan körfezle mevcuttur. Ayrıca İzmir ili içinde Ege Bölgesi'nin önemli akarsularından olan Gediz Nehri'nin aşağı çığırı ile Küçük Menderes akarsuyu bulunur. Kıyı kesimi dağlarının uzanışından dolayı girintili çıkıntılıdır.

İklimi ise; orta enlem kuşağında, denizsel etkilere açık, iç deniz özelliği gösteren körfez yapısı ile Kıyı Ege şeridinin tektonik özelliğine göre iklimsel karakter göstermektedir. Orta Enlem kuşağında yer alması ve kıyı şehri olması nedeni ile Akdeniz iklimi karakteri hâkimdir. Yazlar 
sıcak ve kurak, kışlar ılık ve bol yağışlı, bahar ayları ise geçiş özelliği gösterir. Güneşlenme potansiyeli yüksektir. Rüzgâr durumu denize açık kıyı şeridine farklı topografik yapıları bir arada bulundurması nedeni ile önemli bir potansiyel oluşturmaktadır. Güneşlenme süresi ve yeterli düzeyde yağış miktarına bağlı olarak toprak yapısı tarımsal açıdan uygun iklim özelliğine sahiptir (Atalay, 1994).

\section{VERI VE METOD}

Bu bölüm verilerin toplanması, verilerin işlenmesi, değerlendirme ve analizini oluşturan yöntem ve süreçleri kapsamaktadır.

\subsection{Veri Kaynakları}

\section{- Çalışma Alanı Sınır Verisi}

Bölgeye ait il ve ilçe sınırları Global Administrative Areas (GADM) web sayfasından elde edilmiştir.

\section{- Kırılganlık Gösterge Verileri}

TUIKK ve diğer resmi kaynaklardan elde edilen ilçe ölçeğinde kırılganlık gösterge verileri (Tablo 2) Statistical Package for Social Sciences (SPSS) yazılımında faktör analizine tabi tutulmak üzere hazırlanmıştır (Tablo 3).

Tablo 2. Kırılganlık göstergesi verilerin kaynakları, açıklamaları, referansları

\begin{tabular}{|c|c|c|c|}
\hline Göstergeler & Veri Kaynakları & Açıklama & Referans \\
\hline Yaş & $\begin{array}{l}\text { Türkiye İstatistik } \\
\text { Kurumu (TÜIK), } \\
2017\end{array}$ & $\begin{array}{l}\text { Yaşı ve çocukların fiziki yetersizlikleri, bakıma } \\
\text { muhtaç olma durumu, ekonomik yetersizlikler }\end{array}$ & $\begin{array}{l}\text { Cutter (2003), Hewit (1997), } \\
\text { Kirby vd. (2019) }\end{array}$ \\
\hline Cinsiyet & TÜİK, 2017 & $\begin{array}{l}\text { Kadınları etkilemesi muhtemel sosyo-ekonomik, } \\
\text { fiziki ve psikolojik sorunların erkeklere nazaran } \\
\text { daha fazla olması }\end{array}$ & $\begin{array}{l}\text { Holand ve Julala (2013), } \\
\text { Morrow ve Phillips (1999), } \\
\text { Cutter (2003) }\end{array}$ \\
\hline $\begin{array}{l}\text { Mülteci ve } \\
\text { Sığınmacılar }\end{array}$ & $\begin{array}{l}\text { İzmir İI Göç } \\
\text { İdaresi, } 2017\end{array}$ & $\begin{array}{l}\text { Dil problemi, sosyal dışlanma, afet sonrası } \\
\text { hizmetlere erişimde kısıtıılıklar }\end{array}$ & $\begin{array}{l}\text { Holand ve Lujala (2009), } \\
\text { Cutter (2003), Pulido (2000) }\end{array}$ \\
\hline Eğitim Seviyesi & TÜİK, 2017 & $\begin{array}{l}\text { Sosyo-ekonomik gelişmişliğin ve afetlere karşı } \\
\text { bilinçliliğin eğitim seviyesiyle paralel olması }\end{array}$ & $\begin{array}{l}\text { Heinz Center for Science } \\
\text { Economics and the } \\
\text { Environment (2000), Fekete } \\
(2009)\end{array}$ \\
\hline Engelliler* & TÜİK, 2000 & $\begin{array}{l}\text { Fiziki, psikolojik veya mental yetersizlikler, özel } \\
\text { gereksinimler dolayısıyla bakıma intiyaç durumu, } \\
\text { kaynaklara erişimde sıkıntılar }\end{array}$ & Morrow (1999) \\
\hline $\begin{array}{l}\text { Ekonomik* }^{*} \\
\text { Faktörler (Düşük } \\
\text { Gelir, İşsizlik) }\end{array}$ & TÜİK, 2000 & $\begin{array}{l}\text { Afetin yol açacağı ekonomik risklere açık olma } \\
\text { ve absorbe edememe durumu, sosyal sigorta ve } \\
\text { güvenlik eksiklikleri }\end{array}$ & $\begin{array}{l}\text { Platt (1999), Cutter (2003), } \\
\text { Fekete (2009), Holand ve } \\
\text { Lujala (2009), Kirby vd. } \\
(2019)\end{array}$ \\
\hline Hane Halkı Sayısı & TÜİK, 2017 & $\begin{array}{l}\text { Tek kişilik ve/veya fazla kalabalık hane halkının } \\
\text { karşılaşacağı ekonomik ve psikolojik sorunlar }\end{array}$ & $\begin{array}{l}\text { Heinz Center for Science } \\
\text { Economics and the } \\
\text { Environment (2000), Fekete } \\
(2009)\end{array}$ \\
\hline Medeni Durum & TÜİK, 2017 & $\begin{array}{l}\text { Boşanmış ve dul kişi ve ebeveynlerin } \\
\text { karşılaştıkları sosyal ve ekonomik sorunlar }\end{array}$ & Cupples (2007) \\
\hline $\begin{array}{l}\text { Kırsal/Kentsel } \\
\text { Nüfus }\end{array}$ & TÜİK, 2017 & $\begin{array}{l}\text { Afetlerin, kırsal nüfusun ekonomik faaliyetlerine } \\
\text { zarar verme suretiyle işsizlikte artışa sebep } \\
\text { olması. Kırsal nüfusun sosyal ve sağlık } \\
\text { hizmetlerine erişimindeki kısıtlılık }\end{array}$ & Cova ve Church (1999) \\
\hline Nüfus Yoğunluğu & TÜİK, 2017 & $\begin{array}{l}\text { Yoğun nüfuslu bölgelerin tahliyesinde yaşanan } \\
\text { sorunlar }\end{array}$ & $\begin{array}{l}\text { Cutter, Mitchel ve Scott } \\
(2000)\end{array}$ \\
\hline $\begin{array}{l}\text { Sağlık } \\
\text { Kurumlarının } \\
\text { Yeterliliği } \\
\end{array}$ & $\begin{array}{l}\text { İzmir İI Sağlık } \\
\text { Müdürlüğü, } 2018\end{array}$ & $\begin{array}{l}\text { Afet sonrası kısa ve uzun vadede fiziki, psikolojik } \\
\text { tedavi imkanları ve sağlık personeli yeterliliği }\end{array}$ & Morrow (1999), Cutter (2016) \\
\hline
\end{tabular}


Tablo 3. İzmir ili kırılganlık indeksi geliştirilmesinde kullanılan değişkenlerin tanımlayıcı istatistikleri

\begin{tabular}{|c|c|c|c|c|c|}
\hline Gösterge & Değişken & Min. & Max. & Ort. & $\begin{array}{l}\text { Standart } \\
\text { sapma }\end{array}$ \\
\hline \multirow{2}{*}{ Yaş } & 15 yaşından küçük nüfusun yüzdesi & 12.28 & 24.17 & 18.14 & 2.95 \\
\hline & 65 yaşından büyük nüfusun yüzdesi & 6.47 & 23.81 & 12.33 & 3.94 \\
\hline \multirow[b]{2}{*}{ Eğitim } & İlkokul mezunu nüfusun yüzdesi & 22.65 & 56.69 & 38.29 & 9.39 \\
\hline & Okuma yazma bilmeyen nüfusun yüzdesi & 0.13 & 3.30 & 1.39 & 0.71 \\
\hline \multirow{4}{*}{ Nüfus } & Kırsal nüfusun yüzdesi & 0 & 80.46 & 18.91 & 22.95 \\
\hline & Nüfus Yoğunluğu (km² 'ye düşen kişi sayısı) & 22.29 & 14954.53 & 1462.41 & 3002.54 \\
\hline & Hane halkı sayısı & 2.29 & 3.44 & 2.96 & 0.29 \\
\hline & Mülteci nüfusunun yüzdesi & 0.05 & 9.01 & 1.64 & 2.15 \\
\hline \multirow{2}{*}{ Sağlık } & Engelli nüfusun yüzdesi & 0.06 & 4.11 & 1.64 & 0.85 \\
\hline & Aile Sağlık Merkezi (ASM) Sayısı & 4 & 132 & 39.50 & 43.48 \\
\hline \multirow{2}{*}{ Medeni Durum } & Boşanmış nüfusun yüzdesi & 1.01 & 10.72 & 5.61 & 2.20 \\
\hline & Eşi ölmüş nüfusun yüzdesi & 4.06 & 10.93 & 6.67 & 1.83 \\
\hline \multirow[b]{2}{*}{$\begin{array}{l}\text { Ekonomik } \\
\text { Durum }\end{array}$} & İşsiz nüfusun yüzdesi & 0.47 & 12.51 & 3.17 & 2.60 \\
\hline & $\begin{array}{l}\text { İşçi, hizmetli düzenli maaşla ya da yevmiyeli çalışan nüfusun } \\
\text { yüzdesi }\end{array}$ & 9.98 & 81.21 & 24.27 & 13.47 \\
\hline Cinsiyet & Kadın nüfusun yüzdesi & 41.30 & 52.97 & 49.45 & 2.06 \\
\hline
\end{tabular}

\subsection{Yöntem}

İzmir ili sosyal kırılganlık indeksinin geliştirilmesinde ve haritasının oluşturulmasında aşağıdaki işlem adımları sırasıyla uygulanmıştır.

\subsubsection{Verilerin Normalize Edilmesi}

İstatiksel analiz yapılmadan önce 30 ilçenin kırılganlık verileri standart dağılım özelliklerine sahip olması amacıyla normalleştirilmiştir. Normalleştirme yöntemlerinden Z-Puanı Normalizasyonu yöntemi kullanılmıştır. Farklı teknikler uygulanarak gerçekleştirilebilen normalizasyon işlemi, veri boyutunun uygun aralıklara getirilerek ölçeklendirilmesinde, işlemlerin daha etkin ve daha kolay biçimde yapılmasında sıklıkla kullanılmaktadır. İstatistiksel veri normalizasyonu tekniklerinden biri olan ve yaygın şekilde uygulanan bu yöntemde, ilgili verinin ortalama ve standart sapma değerleri kullanılmaktadır (Khemka, 2003).

$$
X^{\prime}=\frac{X-\operatorname{ortalama}(X)}{\text { standart sapma }(X)}
$$

Eşitlik 1'deki denklem yardımıyla kırılganlık kriterleri normalize edilmiştir (Tablo 4 ve Tablo 5). 
Tablo 4. İlçe bazlı normalize edilmiş kırılganlık verileri

\begin{tabular}{|c|c|c|c|c|c|c|c|c|}
\hline \multirow[b]{2}{*}{ İlçe Adı } & \multicolumn{2}{|c|}{ Eğitim } & \multicolumn{2}{|l|}{ Yaş } & \multicolumn{4}{|l|}{ Nüfus } \\
\hline & 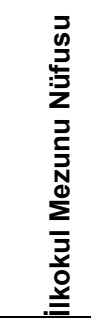 & 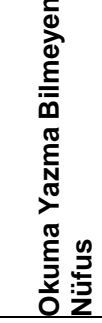 & 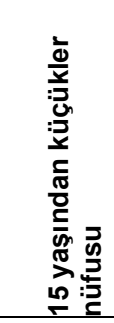 & 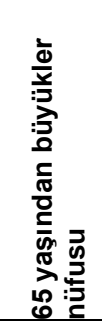 & 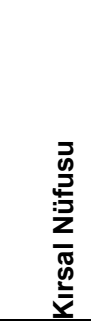 & 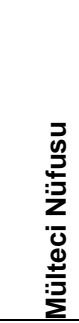 & 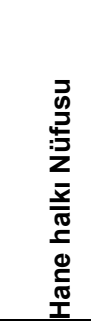 & 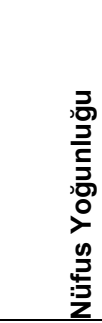 \\
\hline Aliağa & -0.54 & -0.95 & 0.67 & -1.49 & -0.09 & $-0 . \overline{61}$ & $0.6 \overline{5}$ & -0.41 \\
\hline Balçova & -1.45 & -0.81 & -1.55 & 0.49 & -0.91 & -0.72 & -0.88 & 0.85 \\
\hline Bayındır & 1.55 & 2.10 & 0.28 & 0.98 & 1.20 & -0.04 & 0.67 & -0.46 \\
\hline Bayraklı & -0.36 & 0.21 & 0.67 & -0.94 & -0.91 & 0.38 & 0.98 & 0.00 \\
\hline Bergama & 1.08 & 0.71 & -0.19 & 0.47 & 0.79 & -0.70 & 0.67 & -0.47 \\
\hline Beydağ & 1.96 & -0.14 & -0.48 & 0.96 & 1.57 & -0.65 & -0.81 & -0.46 \\
\hline Bornova & -0.43 & 0.01 & 0.23 & -0.99 & -0.84 & 1.83 & 0.74 & 0.16 \\
\hline Buca & -0.41 & -0.29 & 0.52 & -1.18 & -0.87 & 0.49 & 0.88 & 0.40 \\
\hline Çeşme & -0.70 & -0.30 & -0.44 & 0.13 & 0.46 & -0.41 & -0.67 & -0.44 \\
\hline Çiğli & -0.57 & -1.77 & 0.13 & -1.08 & -0.91 & -0.44 & 0.07 & -0.01 \\
\hline Dikili & 0.10 & -0.31 & -1.12 & 1.68 & 0.85 & -0.55 & -1.68 & -0.46 \\
\hline Foça & -0.52 & -0.79 & -1.60 & 0.42 & -0.32 & 0.05 & -1.40 & -0.44 \\
\hline Gaziemir & -1.01 & -0.72 & 0.78 & -1.39 & -0.91 & -0.23 & 0.74 & 0.16 \\
\hline Güzelbahçe & -1.43 & -0.93 & -0.40 & -0.02 & -0.69 & -0.74 & -0.21 & -0.36 \\
\hline Karabağlar & -0.17 & -0.06 & 0.64 & -0.62 & -0.90 & 1.96 & 0.49 & 1.12 \\
\hline Karaburun & 0.07 & -0.94 & -1.99 & 2.91 & 1.82 & 0.43 & -2.35 & -0.48 \\
\hline Karşıyaka & -1.67 & -1.04 & -0.93 & 0.46 & -0.90 & -0.63 & -1.05 & 1.64 \\
\hline Kemalpaşa & 0.75 & 0.65 & 1.53 & -0.93 & -0.08 & -0.11 & 1.40 & -0.44 \\
\hline Kınık & 1.52 & 0.90 & 1.23 & 0.01 & 1.61 & -0.64 & 1.37 & -0.47 \\
\hline Kiraz & 1.70 & 2.72 & 0.55 & 0.24 & 2.64 & -0.71 & 0.49 & -0.46 \\
\hline Konak & -0.25 & 0.99 & -0.42 & 0.43 & -0.91 & 3.43 & -0.70 & 4.49 \\
\hline Menderes & 0.32 & -0.06 & 0.52 & -0.39 & -0.14 & 0.17 & 0.63 & -0.45 \\
\hline Menemen & 0.00 & 0.01 & 1.92 & -1.42 & -0.59 & -0.20 & 1.40 & -0.39 \\
\hline Narlıdere & -1.46 & -0.78 & -0.96 & 0.19 & -0.91 & -0.67 & -0.35 & 0.01 \\
\hline Ödemiş & 1.37 & 0.64 & -0.22 & 0.59 & 0.79 & -0.65 & -0.39 & -0.45 \\
\hline Seferihisar & -0.20 & -0.47 & -0.39 & 0.40 & -0.44 & -0.06 & -0.74 & -0.45 \\
\hline Selçuk & 0.21 & 1.42 & 0.06 & -0.01 & -0.12 & -0.58 & -0.14 & -0.45 \\
\hline Tire & 0.96 & -0.20 & 0.11 & 0.53 & 0.61 & -0.52 & -0.67 & -0.45 \\
\hline Torbalı & 0.38 & 1.13 & 2.04 & -1.17 & -0.63 & 1.75 & 1.68 & -0.38 \\
\hline Urla & -0.78 & -0.95 & -1.19 & 0.76 & -0.32 & -0.66 & -0.46 & -0.46 \\
\hline
\end{tabular}


Tablo 5. İlçe bazı normalize edilmiş kırılganlık verileri (devam)

\begin{tabular}{|c|c|c|c|c|c|c|c|}
\hline \multirow[b]{2}{*}{ İlçe Adı } & \multicolumn{2}{|c|}{ Sağlık } & \multicolumn{2}{|c|}{ Ekonomi } & \multicolumn{2}{|c|}{ Medeni Durum } & \multirow[t]{2}{*}{ Cinsiyet } \\
\hline & 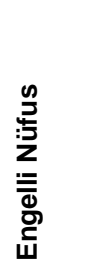 & 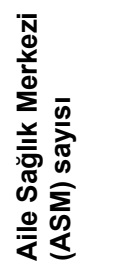 & 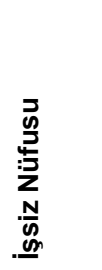 & 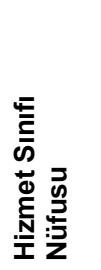 & 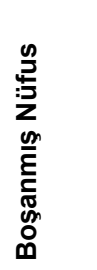 & 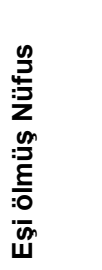 & \\
\hline Aliağa & -0.91 & 0.35 & -0.44 & -0.83 & -0.47 & -1.38 & -2.37 \\
\hline Balçova & -0.29 & -0.60 & -0.33 & -1.82 & 1.10 & 0.01 & 0.76 \\
\hline Bayındır & 1.41 & -1.04 & -0.75 & 1.68 & -1.09 & 2.37 & 0.45 \\
\hline Bayraklı & 0.77 & -0.79 & -1.03 & -0.68 & 0.11 & -0.91 & 0.40 \\
\hline Bergama & 0.57 & -0.57 & -0.22 & 0.91 & -1.02 & 1.06 & 0.13 \\
\hline Beydağ & 1.86 & -1.04 & -0.39 & 1.37 & -2.09 & 1.60 & 0.27 \\
\hline Bornova & -0.34 & -0.25 & 0.62 & -0.65 & -0.05 & -0.94 & 0.44 \\
\hline Buca & -0.69 & 0.18 & 0.15 & -0.56 & 0.22 & -1.08 & 0.26 \\
\hline Çeşme & -0.55 & 0.40 & 0.51 & -0.27 & 0.79 & -0.71 & -0.19 \\
\hline Çiğli & -0.77 & 0.69 & 0.26 & -0.57 & 0.49 & -1.02 & 0.30 \\
\hline Dikili & -0.44 & 1.11 & -0.56 & 0.67 & 0.40 & 0.59 & 0.23 \\
\hline Foça & -0.29 & 1.87 & -0.54 & 0.28 & 0.58 & -0.56 & -3.96 \\
\hline Gaziemir & -0.98 & 0.40 & -0.31 & -1.20 & -0.33 & -1.45 & -0.21 \\
\hline Güzelbahçe & -0.98 & -0.98 & -0.50 & -1.56 & 0.75 & -0.46 & 0.80 \\
\hline Karabağlar & -1.86 & -0.28 & 2.48 & -0.48 & 0.61 & -0.41 & 0.59 \\
\hline Karaburun & 1.45 & -1.95 & -0.43 & 0.42 & 0.72 & 1.72 & -0.61 \\
\hline Karşıyaka & 0.55 & -1.75 & 1.69 & -1.76 & 1.73 & 0.13 & 1.71 \\
\hline Kemalpaşa & -0.49 & 0.30 & -0.68 & 0.49 & -0.87 & -0.48 & -0.11 \\
\hline Kınık & 0.89 & -0.43 & -0.43 & 0.86 & -1.50 & 0.89 & 0.08 \\
\hline Kiraz & 0.73 & -0.66 & -0.59 & 1.79 & -1.85 & 0.77 & 0.01 \\
\hline Konak & 2.89 & -1.31 & 3.59 & -0.47 & 2.32 & 0.73 & 0.81 \\
\hline Menderes & -0.43 & 0.61 & -0.63 & 0.41 & -0.16 & -0.36 & 0.04 \\
\hline Menemen & -0.69 & 1.24 & -0.58 & 0.88 & -0.60 & -1.04 & -0.25 \\
\hline Narlıdere & -0.53 & 1.25 & 0.70 & -1.68 & 0.70 & -0.55 & -0.21 \\
\hline Ödemiş & 0.27 & -0.37 & -0.42 & 0.77 & -0.81 & 1.52 & 0.41 \\
\hline Seferihisar & -0.23 & 1.76 & -0.06 & 0.26 & 0.63 & -0.37 & -0.68 \\
\hline Selçuk & -0.02 & -0.34 & 0.17 & 0.19 & 0.27 & 0.15 & 0.27 \\
\hline Tire & 0.46 & -0.04 & -0.45 & 0.94 & -0.76 & 1.19 & 0.63 \\
\hline Torbalı & -0.84 & 1.15 & -0.71 & 0.46 & -0.47 & -0.80 & 0.01 \\
\hline urla & -0.53 & 1.11 & -0.13 & 0.16 & 0.67 & -0.22 & -0.01 \\
\hline
\end{tabular}

\subsubsection{Veri Setinin Faktör Analizi İçin Uygunluğunun Değerlendirilmesi}

Düzenlenen verilerin faktör analizi işlemine uygunluğunun değerlendirilmesi amacıyla öncelikle SPSS yazılımında Kaiser-Meyer-Olkin ve Bartlett testleri uygulanmıştır. Daha sonra uygun bulunan veri seti SPSS yazılımında faktör analizi işlemi ile değerlendirilerek çalışma alanına ait kırılganlık faktörlerinin faktör yükleri elde edilmiştir.

Korelasyon matrisinin hesaplanması: Faktör analizinde, değişkenler arasında çok güçlü ve yüksek korelasyon aranmaktadır. Değişkenler arasında korelasyonun azalması, faktör analizi sonucu ortaya çıkan sonuçlara olan güveni de azaltmaktadır. Değişkenler arasında aralarında güçlü ve yüksek korelasyon bağı olanlar aynı faktör içinde yer alacaklardır. Dolayısıyla söz konusu değişkenlerin içerisinde yer aldıkları faktörle de bağları oldukça güçlü olacaktır (Nakip, 2003). 
Bartlett Küresellik Testi (Bartlett Test of Sphericity): Bu test korelasyon matrisinin, tüm köşegen elemanları 1, köşegen haricindeki elemanları 0 olan birim matris olup olmadığını görmek amacıyla kullanılmaktadır. Bu testte H0 hipotezi veriler arasında ilişkinin olmadığını, H1 hipotezi veriler arasında ilişki bulunduğunu göstermektedir. Bu testin sonucu olarak katsayının düşük çıkması durumunda $\mathrm{HO}$ hipotezi, yüksek çıkması durumunda da alternatif hipotezi kabul edilmektedir. Sıfır hipotezinin reddedilmediği durumda faktör analizi işlemine devam edilmemelidir. Böyle bir durumda, oluşturulan faktör modelinin kullanılabilmesi için veri setinin tekrardan düzenlenmesi gerekmektedir. Barlett testinin 0.05 den küçük olması beklenmektedir (Akgül ve Çevik, 2003; Hair vd.,1998). Çalışmada Bartlett testinin sonucu önem değeri $0,000<0,05$ olduğundan anlamlıdır (Tablo 6).

Kaiser-Meyer-Olkin (KMO) testi: KMO testi, veri setinin faktör analizi için uygun olup olmadığını belirlemek için kullanılan bir diğer istatiksel test yöntemidir. KMO katsayısının küçük çıkması durumunda, faktör analizi işlemine devam etmek uygun değildir. KMO katsayısının 1'e yaklaşması testin başarısını ve uygunluğunu, katsayının 0.5 'in altında çıkması ise testin başarısızıı̆ını ve faktör analizine uygun olmadığını göstermektedir (Nakip, 2003).

Çalışmada KMO testi katsayıları 0,657 olduğundan, araştırmada örnek büyüklüğü yeterlidir. Modelin faktör analizine uygun olduğu görülmüştür (Tablo 6).

Tablo 6. Kaiser-Meyer-Olkin (KMO) ve Bartlett's test sonuçları

\begin{tabular}{|l|l|l|}
\hline \multicolumn{2}{|l|}{ KMO and Bartlett Testi } \\
\hline KMO Örneklem Uygunluğu Ölçütü & 0,657 \\
\hline $\begin{array}{l}\text { Bartlett'in Küresellik } \\
\text { Testi }\end{array}$ & Yaklaşık Ki-Kare & 491,315 \\
\hline & Df & 105 \\
\hline & Önem &, 000 \\
\hline
\end{tabular}

\subsubsection{Faktör Analizi}

Faktör analizi, aralarında ilişki bulunan veri kümelerini birbirlerinden bağımsız olan ve daha az sayıda yeni veri kümelerine çevirmek, bir yapıyı da ya da oluşuma etki eden değişkenleri sınıflamak için kullanılan istatistiki bir analiz yöntemidir (Özdamar, 2002). Diğer bir ifadeyle, çok sayıda değişkenin birbirleri olan ilişkilerini baz alarak verilerin daha etkin ve özet şeklinde sunulmasına imkân tanıyan çok değişkenli bir analiz tekniğidir (Kurtuluş 1985). Sosyal bilimler, eğitim bilimleri, sağlık bilimleri, doğa bilimleri başta olmak üzere siyaset bilimi ve uluslararası ilişkiler, ekonomi, bayındırlık, psikoloji, sosyoloji, pazarlama ve reklam araştırmaları gibi birçok alanda, yaygın olarak kullanılan bir tekniktir (Karagöz, 1991; Kline,1993; Tavşancıl, 2002).

Çalışmada Tablo 4 ve Tablo 5'de gösterilen değişkenleri faktör grupları altında toplamak ve değişken sayısını azaltmak için faktör analizi kullanılmıştır. Faktör sayısının belirlenmesi, değişkenlerin ortak varyanslarının belirlenmesi, faktörlerin rotasyonu ve yorumlanması işlem aşamaları sırasıyla gerçekleştirilmiştir.

\subsubsection{Faktör Sayısının Belirlenmesi}

Çalışmada faktör analizine tabi tutulan 15 değişkene ait özdeğerler ve varyansların yüzde olarak açıklama oranları incelenmiştir. Özdeğer istatistiği (Eigenvalue) 1'den büyük olan faktörler anlamlı olarak belirlenmiştir. Özdeğer istatistiği 1'den büyük olan 4 faktör söz konusudur. Birinci faktör toplam varyansın \%34,574'ünü, birinci ve ikinci faktörler birlikte toplam varyansın 
\%60,783'ünü, birinci, ikinci ve üçüncü faktörler birlikte toplam varyansın \%79,548'sini, dört faktör ise toplam varyansın \%87,387'sini açıklamaktadır (Tablo 7).

Tablo 7. Açıklanan Toplam Varyans Çizelgesi

\begin{tabular}{|l|l|l|l|l|l|l|}
\hline \multirow{2}{*}{ Faktörler } & \multicolumn{5}{|l|}{ Başlangı̨ Özdeğerleri (Eigenvalue) } & \multicolumn{3}{l|}{ Faktörleştirme Sonrası Değerler } \\
\cline { 2 - 7 } & Toplam & \% Varyans & Kümülatif \% & Toplam & \% Varyans & Kümülatif \% \\
\hline $\mathbf{1}$ & $\mathbf{5 . 1 8 6}$ & $\mathbf{3 4 . 5 7 4}$ & $\mathbf{3 4 . 5 7 4}$ & $\mathbf{5 . 1 8 6}$ & $\mathbf{3 4 . 5 7 4}$ & $\mathbf{3 4 . 5 7 4}$ \\
\hline $\mathbf{2}$ & $\mathbf{3 . 9 3 1}$ & $\mathbf{2 6 . 2 0 9}$ & $\mathbf{6 0 . 7 8 3}$ & $\mathbf{3 . 9 3 1}$ & $\mathbf{2 6 . 2 0 9}$ & $\mathbf{6 0 . 7 8 3}$ \\
\hline $\mathbf{3}$ & $\mathbf{2 . 8 1 5}$ & $\mathbf{1 8 . 7 6 5}$ & $\mathbf{7 9 . 5 4 8}$ & $\mathbf{2 . 8 1 5}$ & $\mathbf{1 8 . 7 6 5}$ & $\mathbf{7 9 . 5 4 8}$ \\
\hline $\mathbf{4}$ & $\mathbf{1 . 1 7 6}$ & $\mathbf{7 . 8 3 9}$ & $\mathbf{8 7 . 3 8 7}$ & $\mathbf{1 . 1 7 6}$ & $\mathbf{7 . 8 3 9}$ & $\mathbf{8 7 . 3 8 7}$ \\
\hline 5 & .528 & 3.520 & 90.907 & & & \\
\hline 6 & .323 & 2.151 & 93.059 & & & \\
\hline 7 & .309 & 2.061 & 95.120 & & & \\
\hline 8 & .293 & 1.956 & 97.076 & & & \\
\hline 9 & .131 & .873 & 97.949 & & & \\
\hline 10 & .092 & .611 & 98.560 & & & \\
\hline 11 & .074 & .496 & 99.056 & & & \\
\hline 12 & .066 & .439 & 99.495 & & & \\
\hline 13 & .043 & .286 & 99.781 & & & \\
\hline 14 & .022 & .150 & 99.930 & & & \\
\hline 15 & .010 & .070 & 100.000 & & & \\
\hline
\end{tabular}

\subsubsection{Değişkenlerin Ortak Varyanslarının Belirlenmesi}

Ortak varyans (communality) analizde bulunan bir değişkenin diğer değişkenlerle paylaştığı varyans miktarı olarak ifade edilmektedir. Ortak varyans değerinin 1'in üzerine çıkması durumunda, araştırmada kullanılan faktörlerin az ya da çok olarak belirlendiği anlaşılmaktadır (Atalay ve diğ.2014)

Tablo 8. Ortak varyanslar

\begin{tabular}{|l|l|l|}
\hline Gösterge & Başlangıç & Çıkarım \\
\hline 15 yaşından küçükler nüfusu & 1.000 & .943 \\
\hline 65 yaşından büyükler nüfusu & 1.000 & .938 \\
\hline İlkokul mezunu nüfusu & 1.000 & .946 \\
\hline Okuma yazma bilmeyen nüfusu & 1.000 & .770 \\
\hline Kırsal nüfus & 1.000 & .885 \\
\hline Nüfus yoğunluğu & 1.000 & .917 \\
\hline Hane halkı sayısı & 1.000 & .943 \\
\hline Mülteci nüfusu & 1.000 & .839 \\
\hline Engelli nüfusu & 1.000 & .764 \\
\hline Aile sağlık merkezi (asm) sayısı & 1.000 & .798 \\
\hline Boşanmış nüfus & 1.000 & .905 \\
\hline Eşi ölmüş nüfus & 1.000 & .931 \\
\hline Işsiz nüfusu & 1.000 & .811 \\
\hline Hizmet sınıfı nüfusu & 1.000 & .914 \\
\hline Kadın nüfusu & 1.000 & .801 \\
\hline
\end{tabular}




\subsubsection{Faktörlerin Rotasyonu ve Yorumlanması}

Faktör analizinin son aşaması döndürülmüş faktör matrisinin oluşturulmasıdır. Döndürülmüş matriste değişkenler ve onların faktörleri arasındaki korelasyonlar görülmektedir. Bir değişken hangi faktör altında mutlak değer olarak büyük ağırlığa sahipse o değişkenin o faktör ile yakın ilişki bulunduğu anlamına gelmektedir. (Atalay ve diğ.2014). Tablo 9'da dört faktör (sütunlar) ve her bir değişkenin faktörler altındaki ağırlıkları gösterilmiştir.

Tablo 9. Döndürülmüş Faktör Matrisi

\begin{tabular}{|l|c|c|c|c|}
\hline \multirow{2}{*}{ DEĞişKEN } & \multicolumn{4}{|c|}{ FAKTÖR } \\
\cline { 2 - 5 } & $\mathbf{1}$ & $\mathbf{2}$ & $\mathbf{3}$ & $\mathbf{4}$ \\
\hline İlkokul mezunu nüfusu & .948 & .123 & -.168 & .053 \\
\hline Hizmet sınıfı nüfusu & .918 & .012 & -.194 & -.185 \\
\hline Kırsal nüfus & .803 & -.311 & -.369 & .090 \\
\hline Okuma yazma bilmeyen nüfusu & .784 & .319 & .150 & .177 \\
\hline Eşi Ölmüş nüfusu & .713 & -.523 & -.045 & .384 \\
\hline Boşanmış nüfusu & -.678 & -.386 & .545 & .009 \\
\hline Engelli nüfusu & .601 & -.412 & .311 & .370 \\
\hline Hane halkı sayısı & .137 & .959 & -.051 & .038 \\
\hline 15 yaşından küçükler nüfusu & .234 & .942 & -.009 & -.002 \\
\hline 65 yaşından büyükler nüfusu & .331 & -.896 & -.061 & .150 \\
\hline Mülteci nüfusu & .068 & .205 & .887 & -.074 \\
\hline Nufus yoğunluğu & -.200 & -.083 & .878 & .314 \\
\hline İşsiz nüfusu & -.228 & -.115 & .836 & .217 \\
\hline Kadın nüfusu & -.045 & .123 & .119 & .877 \\
\hline Aile sağlık merkezi (asm) sayısı & -.225 & .225 & -.165 & -.818 \\
\hline
\end{tabular}

Değişkenler bulundukları satırda mutlak değer olarak en büyük ağırlığı hangi faktör altında almışsa o faktör altında toplanmışlardır. İzmir ili 30 ilçesi için eğitim, yaş, nüfus, medeni durum, sağlık, ekonomi kriterleri altında yer alan 15 adet değişken indirgenerek 4 faktör altında toplanmıştır. Faktörler bünyesinde toplanan değişkenlere göre isimlendirilmiştir (Tablo 10).

Tablo 10. Faktör İsimleri

\begin{tabular}{|c|c|}
\hline DEĞIŞKEN & FAKTÖR ADI \\
\hline İlkolul Mezunu Nüfusu & \multirow{7}{*}{ 1.FAKTÖR } \\
\hline Hizmet Sınıfı Nüfusu & \\
\hline Kırsal Nüfus & \\
\hline Okuma Yazma Bilmeyen Nüfusu & \\
\hline Eşi Ölmüş Nüfusu & \\
\hline Boşanmış Nüfusu & \\
\hline Engelli Nüfusu & \\
\hline Hane Halkı Sayısı & \multirow{3}{*}{ 2.FAKTÖR } \\
\hline 15 Yaşından Küçük Nüfusu & \\
\hline 65 Yaşından Büyük Nüfusu & \\
\hline Mülteci Nüfusu & \multirow{3}{*}{ 3.FAKTÖR } \\
\hline Nufus Yoğunluğu & \\
\hline İşsiz Nüfusu & \\
\hline Kadın Nüfusu & \multirow{2}{*}{ 4.FAKTÖR } \\
\hline Asm Sayısı & \\
\hline
\end{tabular}




\subsubsection{Kırılganlık İndeksinin Hesaplanması}

Faktör analizi işlemi sonucu elde edilen 4 kırılganlık faktörü ve İzmir ili bütünleşik kırılganlık endeksine ilişkin faktör skoru değerleri Tablo 11' de verilmiştir.

Tablo 11. Kırılganlık Endeksi Skorları

\begin{tabular}{|l|c|c|c|c|c|}
\hline ILÇE ADI & $\begin{array}{c}\text { 1. FAKTÖR } \\
\text { ENDEKSi }\end{array}$ & $\begin{array}{c}\text { 2. FAKTÖR } \\
\text { ENDEKSi }\end{array}$ & $\begin{array}{c}\text { 3. FAKTÖR } \\
\text { ENDEKSi }\end{array}$ & $\begin{array}{c}\text { 4. FAKTÖR } \\
\text { ENDEKSi }\end{array}$ & $\begin{array}{c}\text { IZMIR ILI } \\
\text { BÜTÜNLEŞiK } \\
\text { KIRILGANLIK } \\
\text { ENDEKSi }\end{array}$ \\
\hline Aliağa & -0.631 & 0.654 & -0.506 & -1.260 & -1.74 \\
\hline Balçova & -1.497 & -0.895 & -0.399 & 1.103 & -1.69 \\
\hline Bayındır & 1.956 & -0.043 & -0.167 & 0.799 & 2.54 \\
\hline Bayraklı & -0.383 & 0.908 & -0.076 & 0.747 & 1.20 \\
\hline Bergama & 0.938 & -0.022 & -0.526 & 0.498 & 0.89 \\
\hline Beydağ & 1.515 & -0.817 & -0.690 & 0.663 & 0.67 \\
\hline Bornova & -0.359 & 0.866 & 0.871 & 0.074 & 1.45 \\
\hline Buca & -0.650 & 0.944 & 0.280 & 0.055 & 0.63 \\
\hline Çeşme & -0.521 & -0.452 & -0.161 & -0.378 & -1.51 \\
\hline Çiğli & -1.180 & 0.339 & -0.323 & -0.072 & -1.24 \\
\hline Dikili & 0.128 & -1.405 & -0.558 & -0.631 & -2.47 \\
\hline Foça & -0.019 & -1.451 & 0.366 & -3.492 & -4.60 \\
\hline Gaziemir & -1.106 & 1.023 & -0.373 & -0.029 & -0.49 \\
\hline Güzelbahçe & -1.533 & -0.123 & -0.983 & 1.245 & -1.39 \\
\hline Karabağlar & -0.425 & 0.816 & 1.645 & 0.047 & 2.08 \\
\hline Karaburun & 0.626 & -2.679 & -0.113 & 0.203 & -1.96 \\
\hline Karşıyaka & -1.561 & -0.883 & 0.451 & 2.194 & 0.20 \\
\hline Kemalpaşa & 0.415 & 1.355 & -0.362 & -0.135 & 1.27 \\
\hline Kınık & 1.347 & 0.707 & -0.577 & 0.552 & 2.03 \\
\hline Kiraz & 2.073 & 0.368 & -0.512 & 0.312 & 2.24 \\
\hline Konak & 0.624 & -0.666 & 4.495 & 0.585 & 5.04 \\
\hline Menderes & 0.084 & 0.556 & -0.243 & -0.369 & 0.03 \\
\hline Menemen & 0.036 & 1.555 & -0.282 & -0.725 & 0.58 \\
\hline Narlıdere & -1.313 & -0.500 & -0.129 & -0.350 & -2.29 \\
\hline Ödemiş & 0.905 & -0.372 & -0.587 & 0.490 & 0.44 \\
\hline Seferihisar & -0.191 & -0.538 & 0.092 & -1.420 & -2.06 \\
\hline Selçuk & 0.215 & 0.097 & -0.130 & 0.365 & 0.55 \\
\hline Tire & 0.653 & -0.393 & -0.596 & 0.375 & 0.04 \\
\hline Torbalı & 0.498 & 1.852 & 0.571 & -0.855 & 2.07 \\
\hline Urla & -0.648 & -0.803 & -0.475 & -0.587 & -2.51 \\
\hline & & & & & \\
\hline
\end{tabular}

Tablo 11 incelendiğinde pozitif sayılar, mekânsal risklere karşı kırılganlık potansiyelinin yüksek olduğunu, negatif sayılar ise kırılganlık potansiyelinin düşük olduğunu göstermektedir. Analizde, İzmir ili Bütünleşik Kırılganlık İndeksi değerleri 5.04 (en çok kırılgan) ile -4.60 (en az kırılgan) arasında değişmektedir. İzmir ili Sosyal Kırılganlık İndeksi değerlerine göre Konak ilçesinin en çok kırılgan, Foça ilçesinin en az kırılgan olduğu görülmüştür.

\subsubsection{CBS İle Dağılımın Değerlendirilmesi}

Kırılganlık indeksi değerlerinin mekânsal risklere karşı göreceli karşılaştırılması, yüksek ve düşük sosyal kırılganlığa sahip ilçelerin belirlenmesinde önemlidir. Bu nedenle, kırılganlık indeksi değerleri çok düşük, düşük, orta, yüksek ve çok yüksek olmak üzere beş kategoride sınıflandırılmıştır. Kırılganlık indeksi değerleri ArcGIS yazılımı kullanılarak ilçelerin kırılganlık düzeylerini göstermek için haritalandırılmıştır (Şekiller 2-8). 


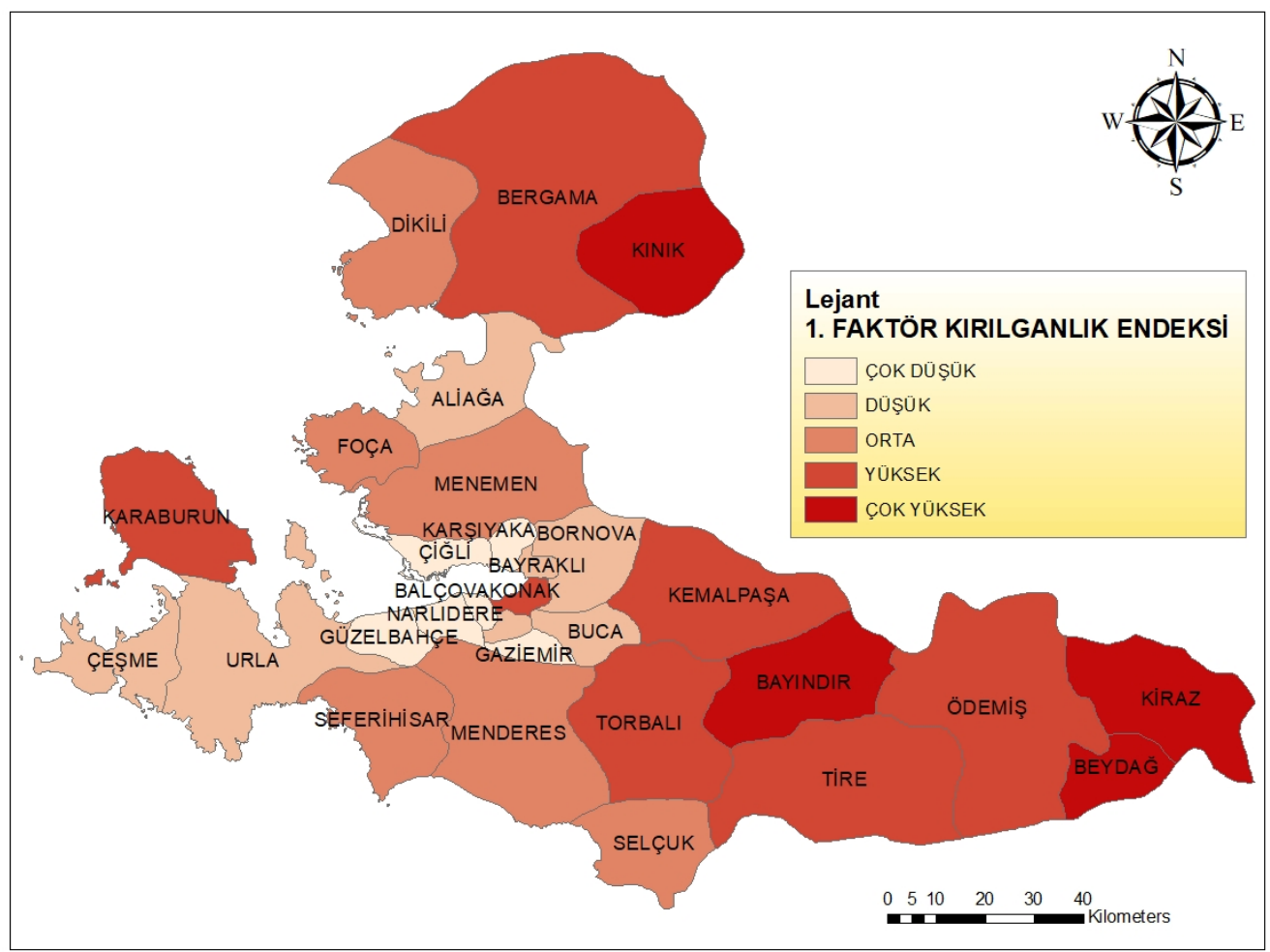

Şekil 2. İzmir ili birinci faktör endeksi bakımından kıııganlık dağılım haritası

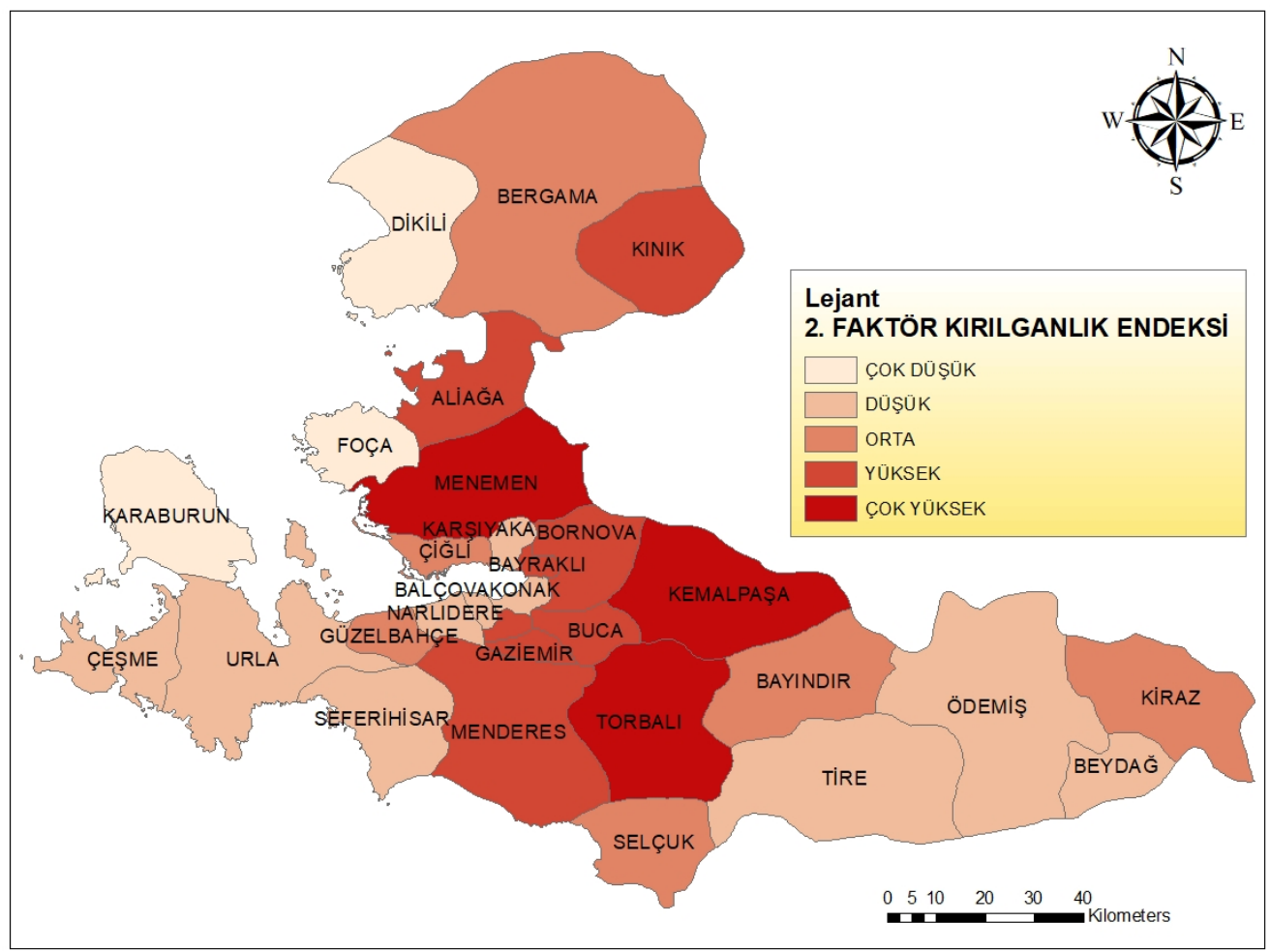

Şekil 3. İzmir ili ikinci faktör endeksi bakımından kııılganlık dağıım haritası 


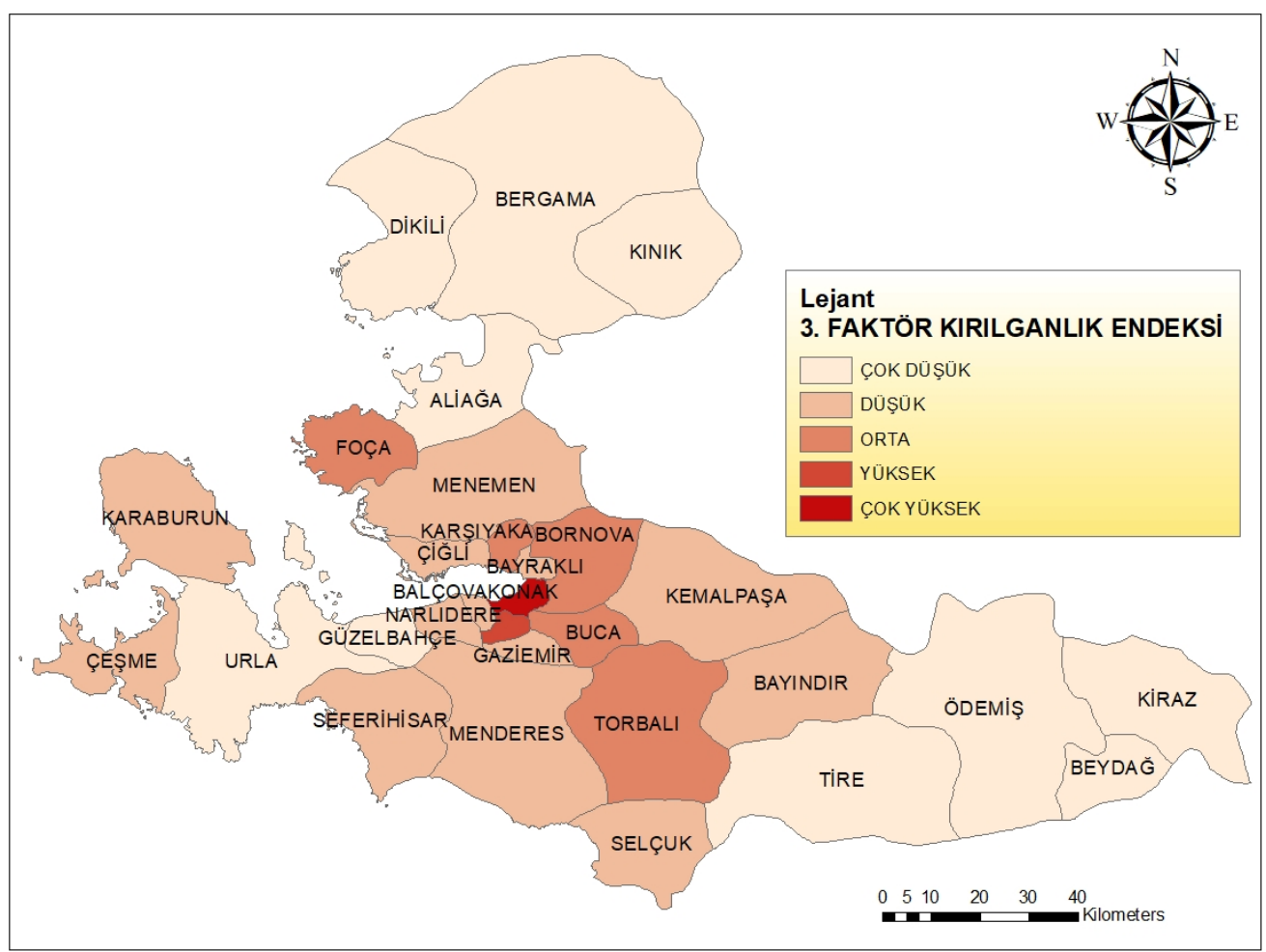

Şekil 4. İzmir ili üçüncü faktör endeksi bakımından kırılganlık dağılım haritası

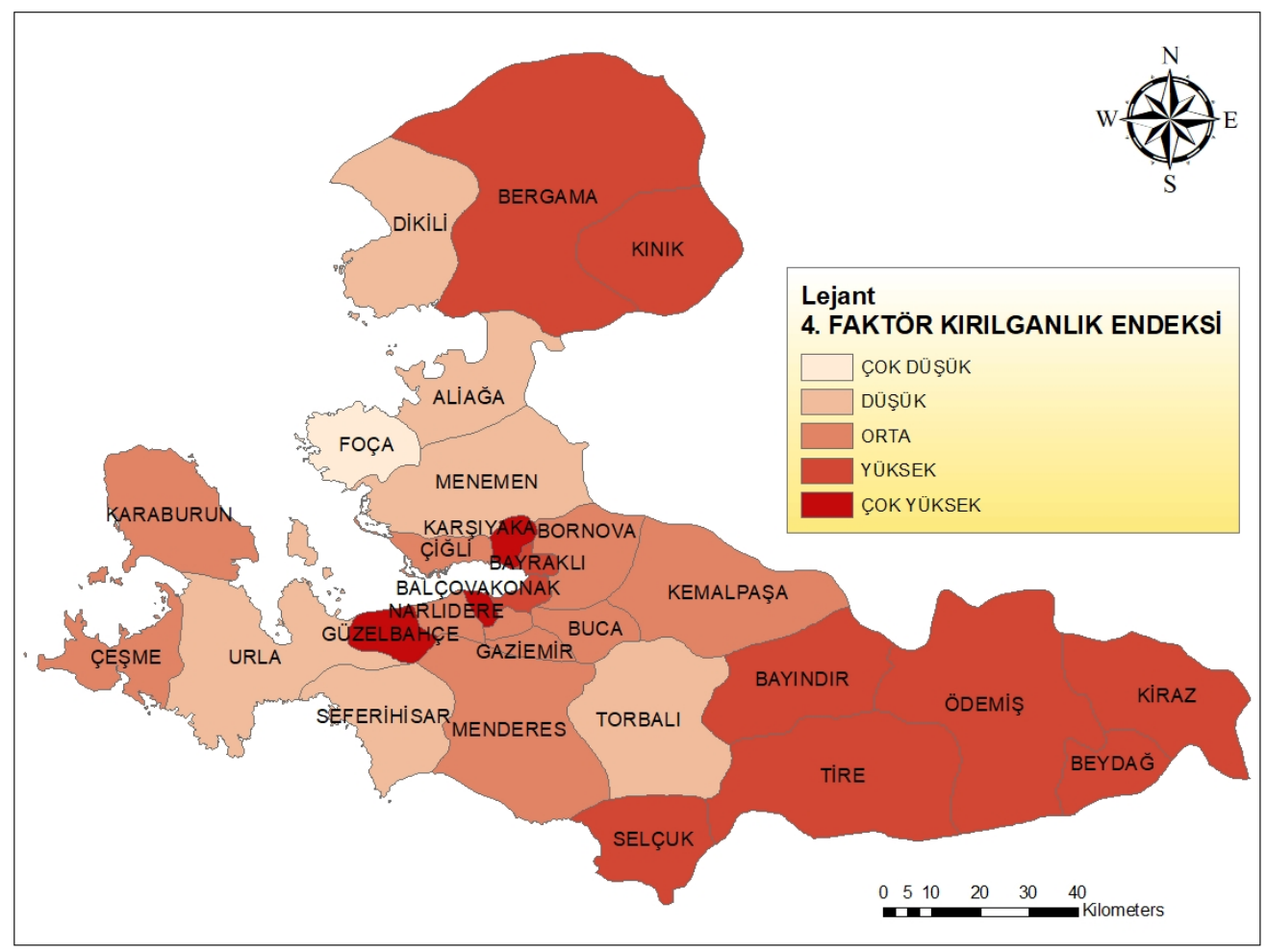

Şekil 5. İzmir ili dördüncü faktör endeksi bakımından kırılganlık dağılım haritası 


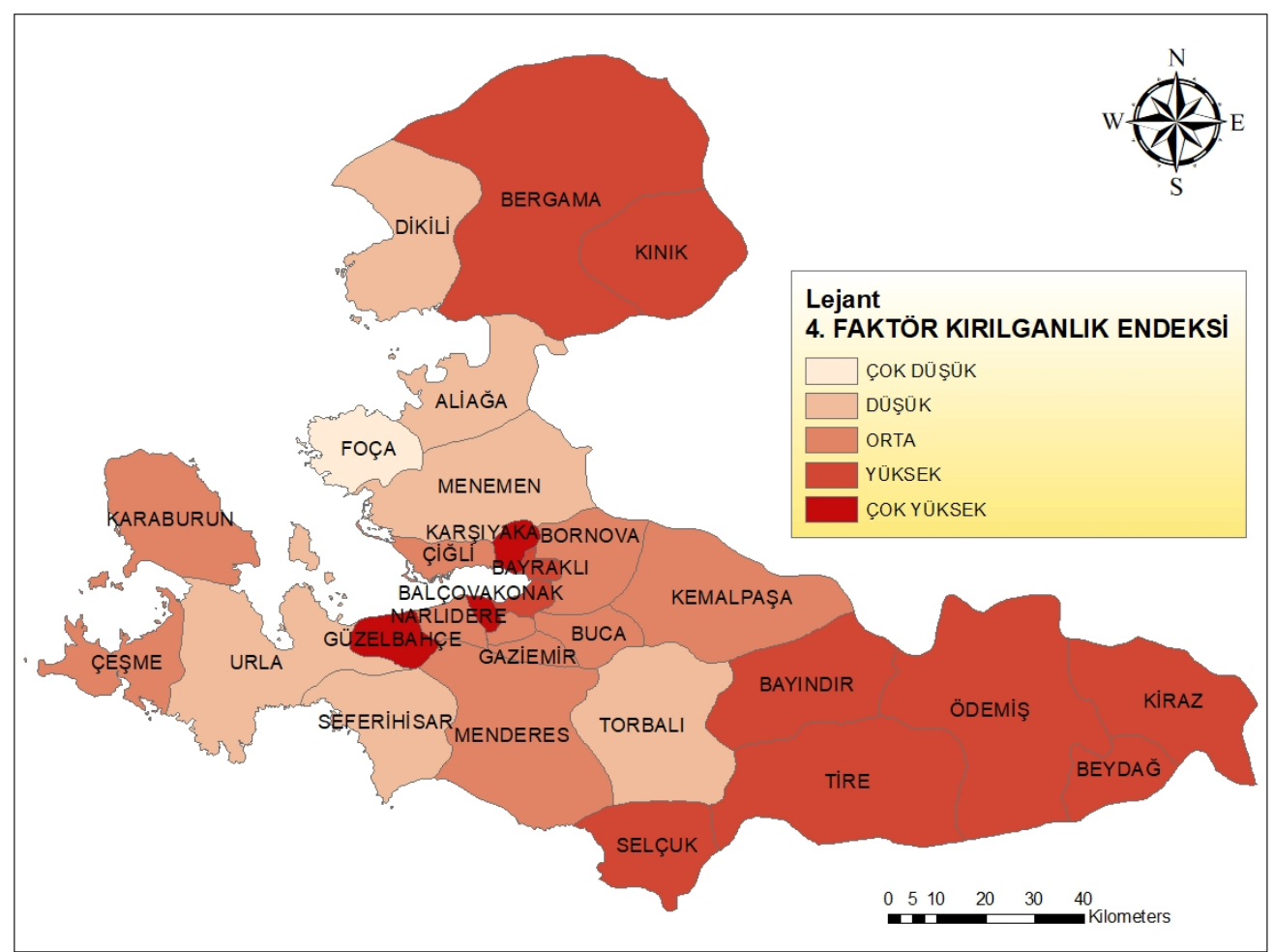

Şekil 6. İzmir ili dördüncü faktör endeksi bakımından kırılganlık dağıım haritası

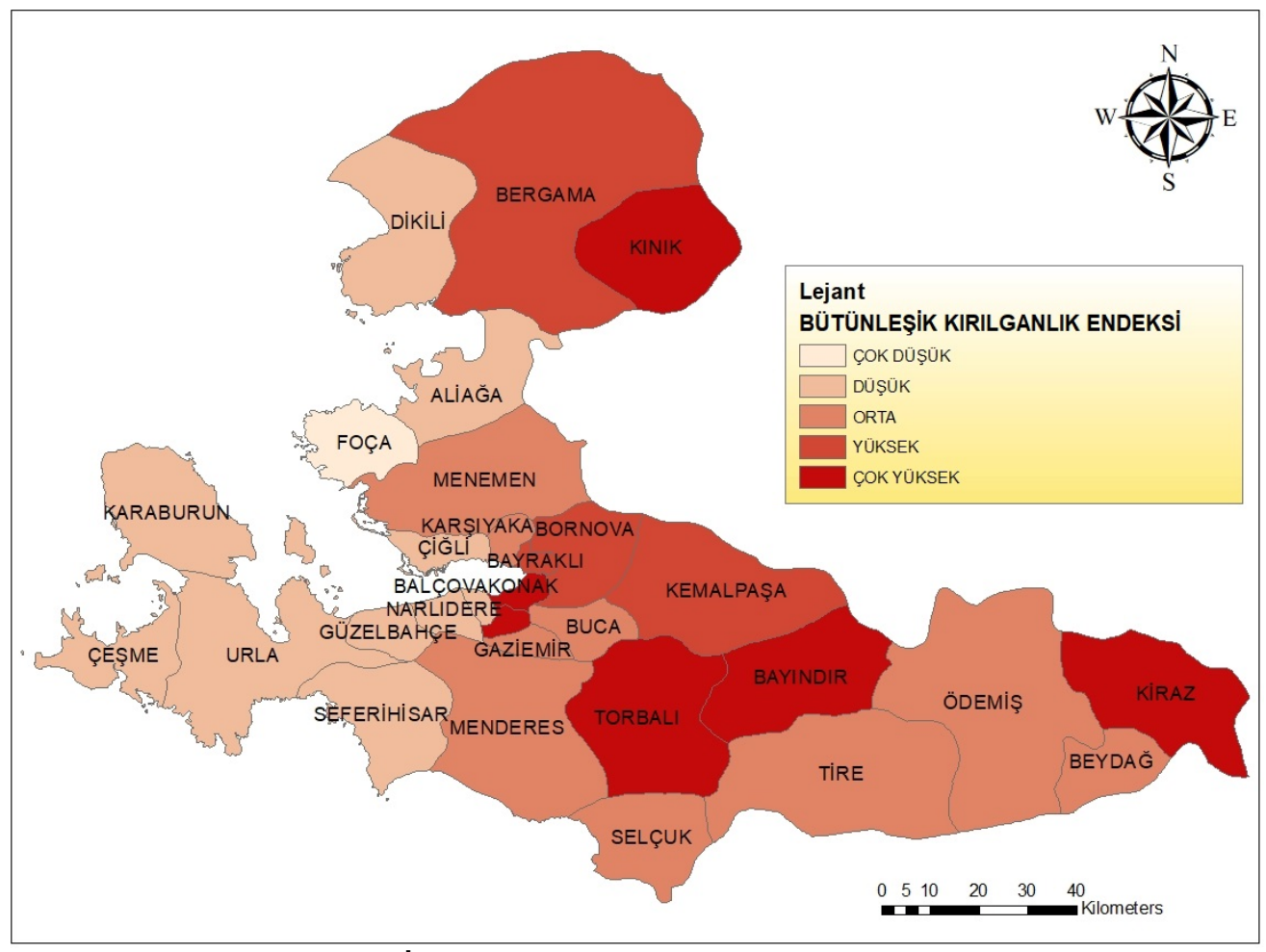

Şekil 7. İzmir ili bütünleşik kııılganlık haritası 


\section{SONUÇ ve ÖNERILER}

İzmir ilinin ilçe bazında sosyal kırılganlık endeksinin hesaplanıp, CBS yöntemleriyle dağılımının haritalandığı bu çalışmada, yüksek nüfus yoğunluk oranına sahip İzmir ilinin, sosyoekonomik ve demografik verileri değerlendirilmiştir. İstatistiki yöntemler sonucunda elde edilen üretilen çıktılar haritalandırılmış ve mekânsal düzeye indirgenmiştir. Bu haritalar, karar verici merciler açısından, özellikle risk sonrasında, kırıgan nüfusun ihtiyaçlarını belirleme ve hazırlık çalışmalarını bu yönde geliştirme açısından önem taşımaktadır. Sosyal kırılganlık analizinde kullanılan parametreler alt gruplara ayrılmıştır. Sağlık, yaş, ekonomi, nüfus özellikleri gibi farklı alt başlık halinde ortaya konulan haritalar, farklı sosyal kırılgan grupların risk sonrası niteliksel ihtiyaçlarını önceden belirlemeyi hedeflemektedir. Mekânsal risk analizlerinden SoVI metodunun açıklandığı bu çalışma, daha küçük ölçekli alanların (mahalle vb.) da sosyal kırılganlık risk haritalarının üretilebileceğini, afetlere hazırlık çalışmalarını daha etkin yürütülebileceğini gösterir niteliktedir. Bu açıdan, afet ve sağlık yönetimi gibi alanlara büyük fayda sağlayacağı düşünülmektedir.

Çalışma sırasında yapılan literatür taramasında, ülkemizde, afetlere hazırlılıkta daha çok altyapısal konularına çalışıldığı, sosyal kırılganlık çalışmalarına gereken önemin verilmediği tespit edilmiştir. Özellikle, CBS yöntemlerinden olan SoVl'nin kullanıldığı herhangi bir çalışmanın bulunmadığı gözlemlenmiştir. Yine, yapılan literatür taraması sonucunda, gelişmiş ülkelerde bu tür çalışmaların belli periyodlarda yapıldığı ve ülkelerin, olası felaketlere karşı sosyoekonomik değerlendirmelerinin CBS ortamında görselleştirdiği gözlemlenmiştir. Pek çok mekânsal riskle yüz yüze gelmesi muhtemel bir lokasyonda konumlanmış olan Türkiye'de, bu tür çalışmaların sayısının artması gerekmektedir. Ayrıca, çalışmanın veri temini aşamasında, resmi kaynakların, güncel veri üretme konusundaki eksiklikleri de ortaya çıkarılmıştır. Sosyoekonomik ve demografik istatistiki veriler konusunda kurumlar arası koordinasyon eksiklikleri giderilmeli ve güncel veri üretimi konusunda daha yenilikçi yöntemler geliştirilmelidir 


\section{KAYNAKLAR}

Akgül, A. ve Çevik, O. (2003). İstatistiksel Analiz Teknikleri. Ankara: Emek Ofset.

Atalay, İ. (1994), Türkiye coğrafyası. Ege Üniversitesi Basımevi.

Atalay, A., Tortum, A., Çodur M.Y., (2014). Faktör Analizi Kullanılarak Trafik Kazalarının Modellenmesi. Uluslararası Trafik ve Ulaşım Güvenligi Dergisi, Cilt 1, Sayı 1.

Cova, T. J. (1999). GIS in emergency management. Geographical information systems, 2, 845858.

Cutter, S. L., Mitchell, J. T., \& Scott, M. S. (2000). Revealing the vulnerability of people and places: a case study of Georgetown County, South Carolina. Annals of the association of American Geographers, 90(4), 713-737.

Cutter, S. L., Boruff, B. J., \& Shirley, W. L. (2003). Social vulnerability to environmental hazards. Social science quarterly, 84(2), 242-261.

Cutter ve Emrich (2016), Social Vulnerability Index (SoVI@): Methodology and Limitations.

Duzgun, H. S. B., Yucemen, M. S., Kalaycioglu, H. S., Celik, K., Kemec, S., Ertugay. K. Deniz A., (2011). An integrated earthquake vulnerability assessment framework for urban areas. Nat Hazards, 59: 917-947.

Fekete, A. (2009). Validation of a social vulnerability index in context to river-floods in Germany. Natural Hazards and Earth System Sciences, 9(2), 393-403.

Hair J. F., Anderson R. E., Tahtam R. L., Black W. C., (1998). Multivariate Data Analysis, Prentice Hall; 374, New Jersey.

İBB (2014). Afet Odaklı Sosyal Hasargörebilirlik Analizi

Karagöz, S. (1991). "Faktör Analizi Tekniği Kullanarak Üniversite Öğrencilerinin Gazete Tercihinde Etkin Faktörlerin Belirlenmesi”, Yüksek Lisans Tezi, İstanbul.

Kirby, R. H., Reams, M. A., Lam, N. S., Zou, L., Dekker, G. G., \& Fundter, D. Q. P. (2019). Assessing Social Vulnerability to Flood Hazards in the Dutch Province of Zeeland. International Journal of Disaster Risk Science, 1-11.

Khemka, A. (2003), A Colloborative Predictive Data Mining Model, Yayınlanmamış Yüksek Lisans Tezi, Faculty of University of Missouri-Kansas City, Missouri.

Kline, P. (1994). An Easy Guide To Factor Analysis, Routledge, London.

Kurtuluş, K. (1985). Pazarlama Araştırmaları. İstanbul: İstanbul Üniversitesi Yayın No: 2789.

KUZUCUOGLU, A. H. (2013). Risk Management Strategy for Cultural Heritage.

Mavhura ve diğerleri (2017), An approach for measuring social vulnerability in context: The case of flood hazards in Muzarabani district, Zimbabwe

Menteşe, E. Y., Konukcu, B. E., Kılıç, O., Khazai, B. (2016). The megacity indicator system for disaster risk management: integrated assessment of physical risks in Istanbul. Management of Natural Disasters, 92, 203.

Morrow, B. H. (1999). Identifying and mapping community vulnerability. Disasters, 23(1), 1-18. Nakip, M. (2003). Pazarlama Araştırmaları Teknikler ve (SPSS Destekli) Uygulamalar. Ankara:Seçkin Yayıncılık.

Schmidtlein ve diğerleri (2008), A Sensitivity Analysis of the Social Vulnerability Index

Tavşancıl, E. (2002). Tutumların Ölçülmesi ve SPSS ile Veri Analizi. Ankara: Nobel Yayıncılık., Özdamar, K. (2002). Paket Programlar ile istatistiksel Veri Analizi. Eskişehir: Kaan Kitabevi.

(https://www.ibb.istanbul/News/Detail/33859)

http://www.ibb.gov.tr/trTR/SubSites/DepremSite/Documents/SOHAG RAPOR Bask\%C4\%B1.p $\underline{\mathrm{df}}$ 